\title{
MK3 controls Polycomb target gene expression via negative feedback on ERK
}

\author{
Peggy Prickaerts ${ }^{1,3}$, Hanneke EC Niessen ${ }^{1 \dagger}$, Emmanuèle Mouchel-Vielh ${ }^{3 \dagger}$, Vivian EH Dahlmans ${ }^{1}$, \\ Guus GH van den Akker ${ }^{1}$, Claudia Geijselaers ${ }^{1}$, Michiel E Adriaens ${ }^{2}$, Frank Spaapen ${ }^{1}$, Yoshihiro Takihara ${ }^{4}$, \\ Ulf R Rapp ${ }^{5}$, Frédérique Peronnet ${ }^{3}$ and Jan Willem Voncken ${ }^{1 *}$
}

\begin{abstract}
Background: Gene-environment interactions are mediated by epigenetic mechanisms. Polycomb Group proteins constitute part of an epigenetic cellular transcriptional memory system that is subject to dynamic modulation during differentiation. Molecular insight in processes that control dynamic chromatin association and dissociation of Polycomb repressive complexes during and beyond development is limited. We recently showed that MK3 interacts with Polycomb repressive complex 1 (PRC1). The functional relevance of this interaction, however, remained poorly understood. MK3 is activated downstream of mitogen- and stress-activated protein kinases (M/SAPKs), all of which fulfill crucial roles during development. We here use activation of the immediate-early response gene ATF3, a bona fide PRC1 target gene, as a model to study how MK3 and its effector kinases MAPK/ERK and SAPK/P38 are involved in regulation of PRC1-dependent ATF3 transcription.
\end{abstract}

Results: Our current data show that mitogenic signaling through ERK, P38 and MK3 regulates ATF3 expression by PRC1/chromatin dissociation and epigenetic modulation. Mitogenic stimulation results in transient P38-dependent H3S28 phosphorylation and ERK-driven PRC1/chromatin dissociation at PRC1 targets. H3S28 phosphorylation by itself appears not sufficient to induce PRC1/chromatin dissociation, nor ATF3 transcription, as inhibition of MEK/ERK signaling blocks BMI1/chromatin dissociation and ATF3 expression, despite induced H3S28 phosphorylation. In addition, we establish that concomitant loss of local H3K27me3 promoter marking is not required for ATF3 activation. We identify pERK as a novel signaling-induced binding partner of PRC1, and provide evidence that MK3 controls ATF3 expression in cultured cells via negative regulatory feedback on M/SAPKs. Dramatically increased ectopic wing vein formation in the absence of Drosophila MK in a Drosophila ERK gain-of-function wing vein patterning model, supports the existence of MK-mediated negative feedback regulation on pERK.

Conclusion: We here identify and characterize important actors in a PRC1-dependent epigenetic signal/response mechanism, some of which appear to be nonspecific global responses, whereas others provide modular specificity. Our findings provide novel insight into a Polycomb-mediated epigenetic mechanism that dynamically controls gene transcription and support a direct link between PRC1 and cellular responses to changes in the microenvironment.

Keywords: Polycomb, MAPKAPK3, MK3, ERK, epigenetic, feedback, dynamic

\footnotetext{
*Correspondence: W.Voncken@maastrichtuniversity.nl

${ }^{\dagger}$ Equal contributors

'Department of Molecular Genetics, GROW School for Oncology and Developmental Biology, Maastricht University, Universiteitssingel 50, 6229ER, Maastricht, The Netherlands

Full list of author information is available at the end of the article
}

\section{Biomed Central}

(C) 2012 Prickaerts et al.; licensee BioMed Central Ltd. This is an Open Access article distributed under the terms of the Creative Commons Attribution License (http://creativecommons.org/licenses/by/2.0), which permits unrestricted use, distribution, and reproduction in any medium, provided the original work is properly cited. 


\section{Background}

Mitogen- and stress-activated protein kinase (M/SAPK) signaling pathways relay environment-to-gene information and enable physiologically appropriate cellular responses [1]. MK3 is an interaction partner of extracellular signal-regulated kinase (ERK) and P38 and is targeted by all three M/SAPK signaling cascades [2]; these phosphorylation cascades induce multiple responses, among which is altered gene transcription $[3,4]$.

We previously demonstrated that mitogen-activated protein kinase-activated protein kinase 3 (MK3/3pK/ MAPKAPK3) binds Polycomb repressive complex 1 (PRC1), via the self-association motif (SAM)-domain of PHC [5]. Polycomb Group and Trithorax Group proteins maintain transcriptionally repressed and activated epigenetic states respectively and as such are part of an important cellular transcriptional memory system. Although PRC1-mediated transcriptional repression has long been considered a stable repressive state, increasing evidence indicates that PRC1 repression is a dynamic process [6,7]. Genome-wide chromatin association studies have revealed changes in Polycomb/chromatin distribution and transcriptional reprogramming during lineage commitment and differentiation [8-10]. As M/SAPKs and MKs also play important roles in differentiation, development and cell proliferation, the physical association of PRC1 and MK3 suggests a functionally relevant connection. We have previously established that PRC1/chromatin dissociation correlates with their phosphorylation status during cell cycle progression [11]. Subsequently, we showed that acute mitogenic and stress signaling also results in PRC1/chromatin dissociation [5]. The molecular mechanisms that underlie this dynamic relocation of PRC1 and the exact role of MK3 in signaling to chromatin remained unknown. We here hypothesized that M/SAPKMK signaling imposes a molecular mechanism by which cells regulate $\mathrm{PRC} 1 /$ chromatin association and PRC1 target gene expression in response to environmental cues. We used the previously identified PRC1 target gene ATF3 to study PRC1-mediated transcriptional regulation [12]. ATF3 is an immediate-early response gene (IEG) [13]; relevantly, ERK and MK have been implicated in IEG
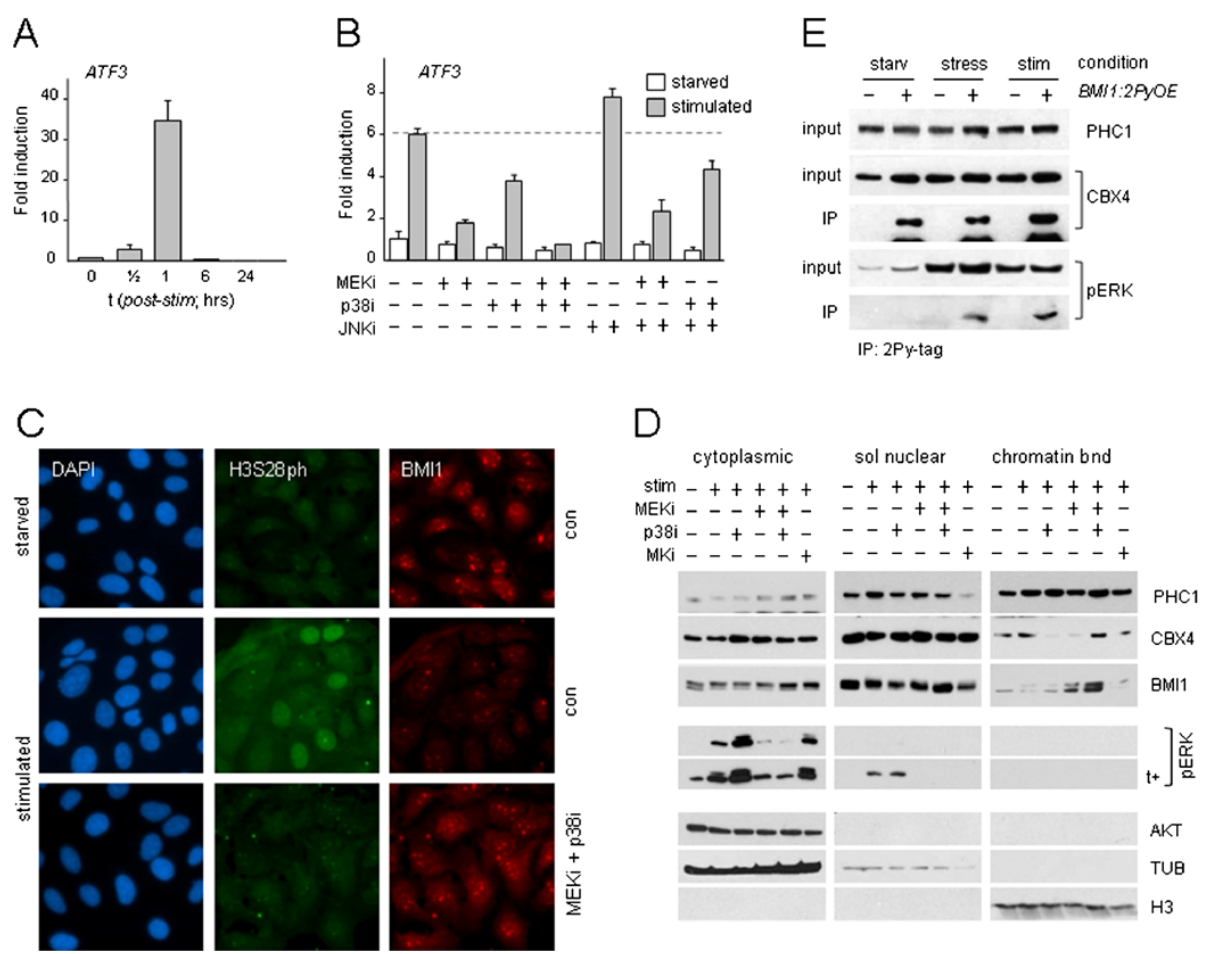

Figure 1 PRC1 target gene expression is controlled by M/SAPKs. (A,B) PRC1 target gene ATF3 expression (mRNA) in mitogen-stimulated (FCS/TPA) TIG3 cells, in the absence or presence of kinase inhibitors; data \pm SD. (C) H3S28ph and BMl1 staining in starved or mitogen-stimulated U2-OS cells; DAPI: nuclear counterstain. (D) Subcellular PRC1 protein distribution in starved and stimulated U2-OS cells; nuclear soluble and chromatin-bound fractions were proportionally loaded; nuclear fractions correspond to approximately three to four cytoplasmic equivalents. Cytoplasmic and nuclear fractions were always loaded on the same gel for direct quantitative comparison (corresponding sections are shown separately; representative experiment shown). AKT, TUB, H3: fractioning and loading controls (quantification chromatin-bound BMI1: compare Additional file 1: Figure S1C). (E) Induced interaction of pERK and BMI1 in response to mitogens (stim) or selenite (stress) in U2-OS cells; loading controls: PRC1 proteins CBX4 and PHC1; PCR1 interaction confirmed by BMI1/CBX4 co-immunoprecipitation (co-IP); +/-: transfected BMI1-2Py CDNA. 
activation [14]. Therefore, mitogen-induced ATF3 activation represents a suitable model to study the biological relevance of ERK/MK3/PRC1 signaling. Our current data establish that ATF3 expression is dynamically controlled by MAPK/MK/PRC1, and identify important players in an epigenetic switch-module in response to changes in the cellular microenvironment.

\section{Results and Discussion}

M/SAPK signaling controls PRC1 target gene transcription To determine how M/SAPKs are implicated in Polycombmediated repression, transcription of the PRC1 target gene ATF3 was measured in the presence or absence of kinase inhibitors. All cells were serum starved (G0/G1-arrest) prior to stimulation throughout this study, to avoid interference by late S/G2-associated PRC1/chromatin dissociation [11]. ERK, P38 and jun N-terminal kinase (JNK) are all phosphorylated in response to mitogenic stimulation (Additional file 1: Figure S1A). Consistent with immediate-early response kinetics, ATF3 mRNA levels rapidly increase and peak at 60 minutes after stimulation (Figure 1A). P38 inhibition (p38i) and MEK/ERK inhibition (MEKi) both substantially and reproducibly reduce ATF3 induction; the effect of ERK inhibition is consistently stronger than $\mathrm{p} 38 \mathrm{i}$ ( \pm 3 - to 4 -fold versus \pm 1.5 - to 2 fold, respectively); combining both inhibitors blocks ATF3 expression completely; JNK inhibition (JNKi) slightly enhances ATF3 induction (Figure 1B). Various PRC1 proteins cluster to pericentromeric heterochromatinassociated Polycomb Group nuclear bodies (PcG-NB) in several cancer cell lines $[11,15,16]$. Using PcG-NB/ chromatin dissociation in $\mathrm{U} 2-\mathrm{OS}$ cells as a read-out for PRC1/ chromatin binding $[5,11]$, we find that PcG-NB/chromatin dissociation correlates well with increased histone H3 phosphorylation at Ser28 (H3S28ph) in mitogenstimulated control cells, in concordance with previous observations [5], and that combined MEKi/p38i blocks both events (Figure 1C). H3S28 is phosphorylated by numerous triggers and MAPKAPK-family kinases, including RSKs and MSKs [17,18]. Of note, immediate-early response genes (IEG) are controlled by MKs and local H3S28 phosphorylation $[14,19]$. In the context of mitogenic stimulation, we find that P38i alone can block H3S28ph and chromatin dissociation of the PRC1 protein BMI1, whereas BMI1/chromatin binding is largely retained when ERK signaling is interrupted (MEKi), without affecting H3S28ph (Additional file 1: Figure S1B). These results support the notion that P38 targets H3S28 and that ERK signaling may target PRC1/chromatin association, and possibly PRC1 protein function and/or interaction. To examine the effect of mitogenic stimulation on subnuclear distribution of PRC1 proteins (in the presence or absence of kinase inhibitors), cells were differentially extracted to yield cytoplasmic, soluble nuclear and chromatin-bound fractions. We previously found that the PRC1 protein PHC1 undergoes a global chromatin redistribution in response to cell stress in contrast to some other PRC1 members [5]; as such, determination of total (that is, PcG-NB and global) PRC1 protein/chromatin association is pivotal. Of note: mitogenic stimulation differentially affects global PHC1/, CBX4/ (both increased) and BMI1/chromatin association (decreased), suggesting differential regulation of PRC1 members by M/SAPKs. Consistent with this, single inhibitor treatment (p38i or MEKi) clearly affects chromatin association of PRC1 proteins in distinct ways (Figure 1D). Combined inhibitor treatment of stimulated cells shows that more BMI1 remains chromatin-associated, consistent with the immunofluorescence (IF) analysis (Figure 1D,C, Additional file 1: Figure S1C); also CBX4/ and $\mathrm{PHC1/chromatin} \mathrm{binding} \mathrm{are} \mathrm{increased}$ under p38i/MEKi conditions. The fluctuation of CBX4 levels suggests a direct involvement of phosphorylation in relation to chromatin association. Besides differential phosphoregulation of PRC1 proteins by M/SAPKs, the above findings predicted an interaction between MAPK and PRC1, downstream of mitogenic signaling. Indeed, co-immunoprecipitation analyses confirm a signalinginduced interaction between pERK and PRC1 complexes (Figure 1E). The PRC1/pERK interaction is counteracted by P38 signaling, as more pERK co-precipitates in a PRC1-directed IP in p38i cells (Additional file 1: Figure S1D, compare Figure 1D), in support of cross-talk between kinases at multiple levels. The combined data demonstrate that mitogenic signaling, via both activated P38 and ERK, converges at the level of PRC1/chromatin regulation and target-gene activation, and establish a relevant functional interaction between these signal transducers and PRC1.

\section{Transcription correlates with PRC1 dissociation, not loss of $\mathrm{H} 3 \mathrm{~K} 27 \mathrm{me} 3$}

We next studied changes in PRC1 (CBX8, PHC1) chromatin occupation and H3K27me3 marks at established PRC1 target genes [12]. CBX8 and PHC1 show distinct chromatin-occupation profiles: whereas CBX8 is exclusively enriched at PRC1 target loci and is released upon serum stimulation at most targets, PHC1 appears present also at non-target genes and shows opposing dissociation dynamics at targets (decreased; ATF3; HOXA11) and nontargets (increased; $p 15$ exon1, CCNA2, p14 ${ }^{A R F}$ exon1) upon stimulation (Figure 2A). The observed changes in PHC1 occupation are consistent with enhanced chromatin association in response to mitogens (compare Figure 1D). We find a clear correlation between simultaneous chromatin dissociation of $\mathrm{CBX} 8$ and $\mathrm{PHC} 1$, and activation of expression at the ATF3 locus (Figure 2A, Additional file 2: Figure $\mathrm{S} 2 \mathrm{~A}$ ). As CBX8 levels remain unaltered throughout the duration of the experiment, this does not account for 


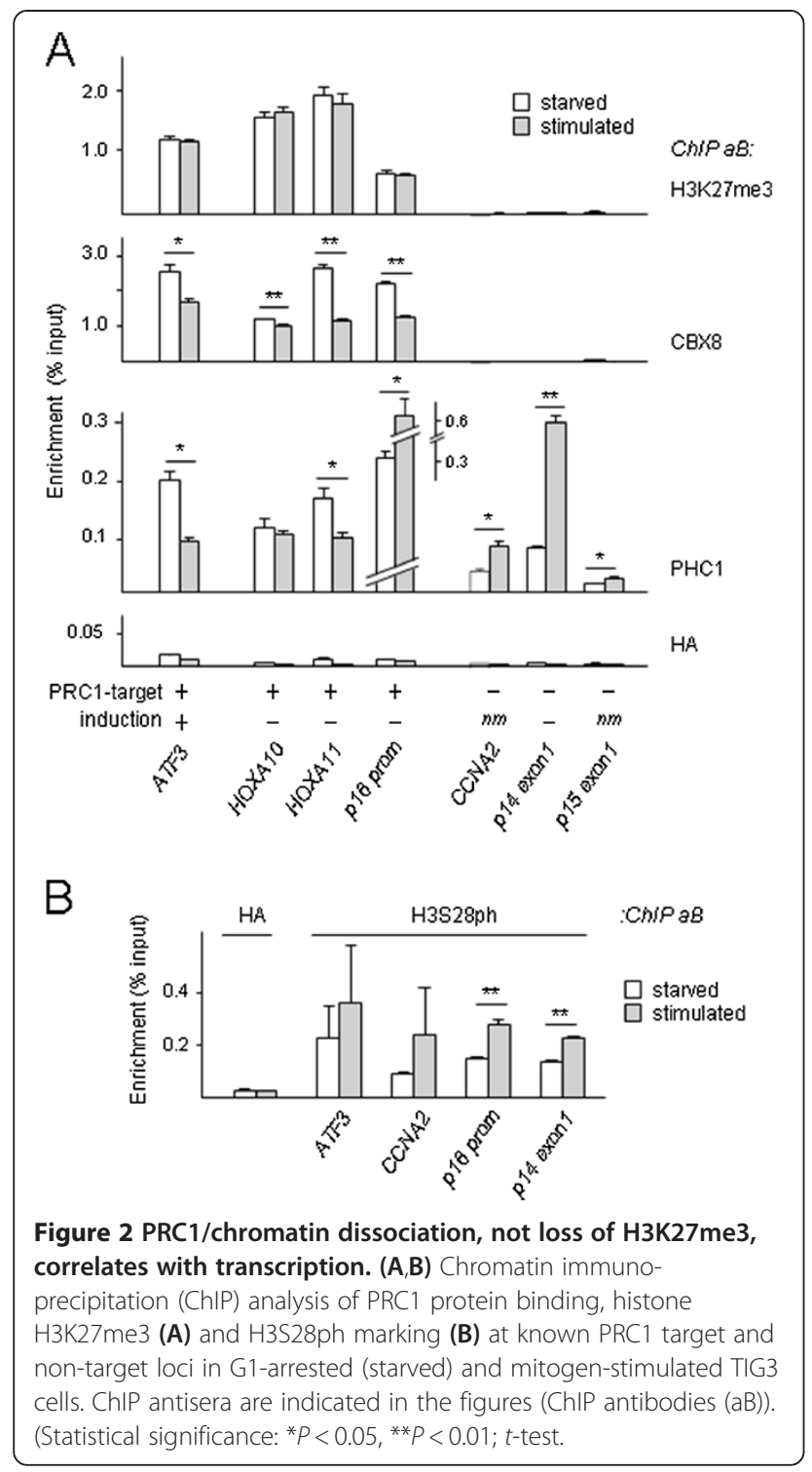

the reduced $\mathrm{CBX} 8 /$ chromatin association (Additional file 2: Figure $\mathrm{S} 2 \mathrm{~B})$. In contrast to $\mathrm{CBX} 8, \mathrm{PHC1}$ increases at all non-induced loci (Figure 2A, Additional file 2: Figure S2A). The contrasting chromatin-binding dynamics of CBX8 and PHC1 in response to signaling are in good agreement with our previous observation that $\mathrm{PHC1} /$ chromatin binding appears to increase globally in the context of cell cycle progression or cell stress, whereas detection of other PRC1 members in PcG-NB (like BMI1, CBX4 and RNF2) is reduced [5,11]. Of note, PHC/PRC1core complex association was reported to be relatively weak [20]. In addition, purified PHC1 is known to reside in non-PRC complexes [21]. Combined, these results indicate that PHC1 occupation occurs without the need for simultaneous CBX8 binding, and further supports the notion of differential regulation of PRC1-complex members.
The observation that both $\mathrm{CBX} 8$ and $\mathrm{PHC} 1$ removal correlate with $A T F 3$ expression, whereas $\mathrm{PHC} 1$ is retained/ increased at the CDKN2A/INK4A locus (Figure 2A, Additional file 2: Figure S2A) suggests that multiple/all PRC1core complex members may need to dissociate at crucial regulatory regions to allow active transcription. It is conceivable that signaling through $\mathrm{M}(\mathrm{S}) \mathrm{APK} / \mathrm{MK} 3 / \mathrm{PRC} 1$ changes the local epigenomic state from a repressed/ poised state $[12,22,23]$ to a 'de-repressed' and eventually fully transcriptionally active state through progressive loss of PRC1 members.

Consistent with a global mitogen-induced increase of H3S28ph, ChIP analysis shows increased H3S28ph enrichment at PRC1 targets as well as non-targets; this epigenetic change occurs independent of transcriptional induction (Figure 2B, Additional file 2: Figure S2A). Remarkably, the unaltered $\mathrm{H} 3 \mathrm{~K} 27 \mathrm{me} 3$ occupation at the ATF3 promoter suggests that transcriptional activation of PRC1 target genes occurs without concomitant loss of H3K27me3 (Figure 2A). Thus, although PcG-NB/chromatin dissociation and H3S28ph correlate well [5,24,25], H3S28ph by itself does not determine transcriptional status. In addition, our findings argue that local maintenance of H3K27me3 does not obstruct transcriptional reactivation of PCR1 targets. The recently reported presence of H3K27me3 marks on active promoters supports this notion [26]. Whether or not the H3K27me3 mark needs to be removed at reactivated genes remains contradictory at this point [24-26], and may, besides on models and tools used, depend on the subgenic location of epigenetic modifications (possibly in conjunction with other modifications). Consistent with this idea, repressive H3K27me3 marking correlates best with transcription at loci that display 'blanketing'-type H3K27me3 enrichment, that is, gene body-wide (downstream of the transcription start site (TSS)) [26]. It is conceivable that H3K27me3 promoter marking defines a specific class of response factors, which are dynamically controlled by rapid removal of PRC1 complexes. Thus far, our H3S28ph analyses suggest that H3S28ph, like CBX8 dissociation, is a global event; despite being essential for PRC1 target gene activation, it is clearly not the sole determining factor and as such is unlikely to specify regulation only at PRC1 target genes. Co-occurrence of methylphosphoryl modifications on adjacent histone lysines and serines was proposed to act as a binary epigenetic switch mechanism, by affecting chromoboxdomain binding to histone-trimethyl marks [24,27-29]; Interestingly, also EZH2/chromatin dissociation at musclespecific promoters during myogenesis appears driven by local H3K27 methyl/H3S28 phosphoryl modification [30,31]. The simultaneous detection of local H3S10ph and HP1 binding, however, seemingly challenges the strictness of the methylphosphoryl switch concept [32]. Irrespective 


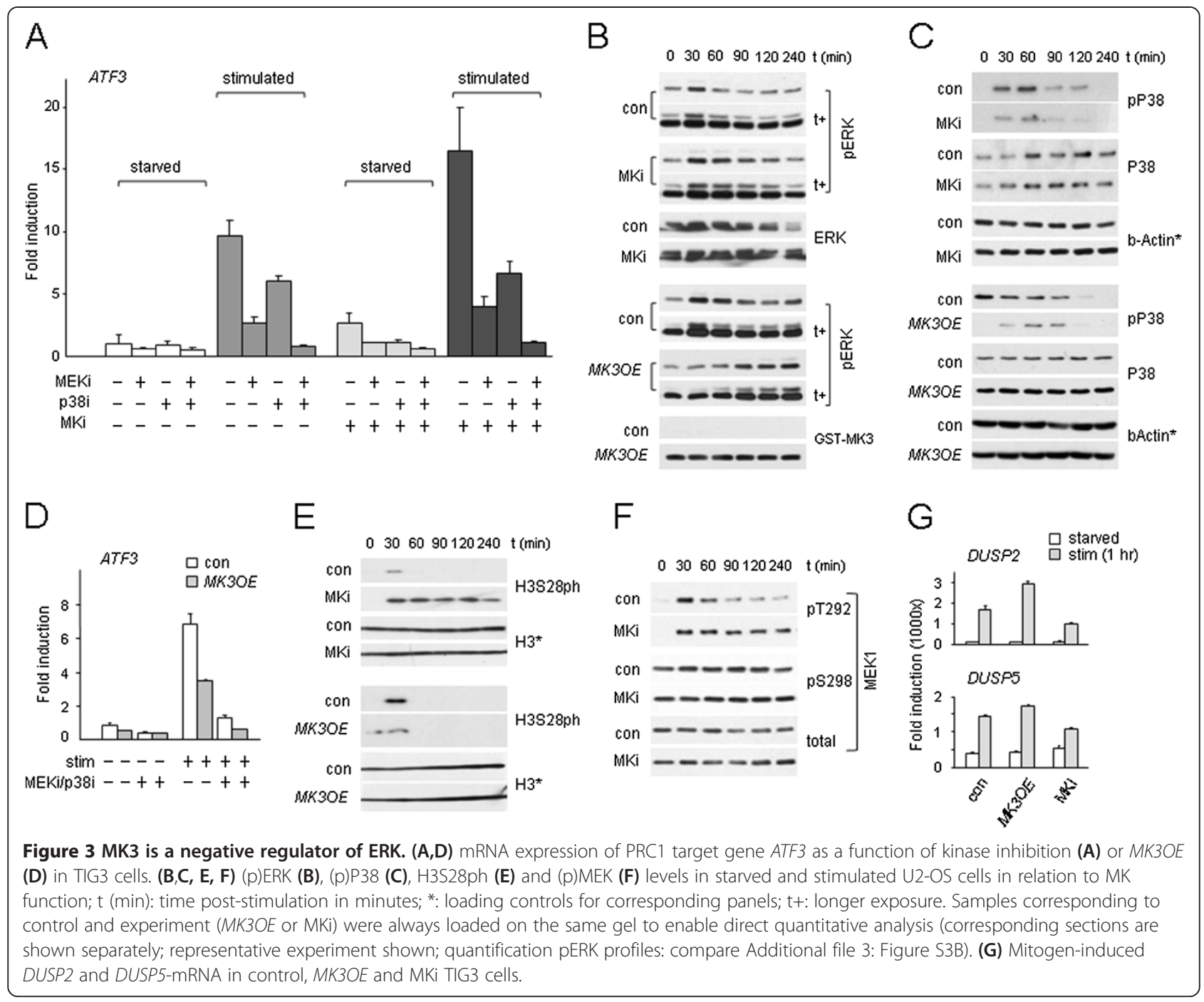

of the exact mechanism, our combined molecular epigenetic analyses suggest PRC1 target gene activation does not require loss of $\mathrm{H} 3 \mathrm{~K} 27 \mathrm{me} 3$ and point to chromatin dissociation of multiple PRC1 proteins as an important event in transcription initiation.

\section{MK3 negatively regulates ERK signaling}

To determine the role of MK in PRC1 target gene regulation, we next studied the effects of MK inhibition or MK protein level modulation on ATF3 gene expression in TIG3 and U2-OS cells. MK inhibition (MKi) releases basal repression of $A T F 3$ in starved MKi cells and allows for more robust ATF3 mRNA induction; in contrast, treatment with MEKi or p38i, both suppress transcription (Figure 3A, Additional file 3: Figure S3A). Of note: MKi does not show an added effect on ATF3 mRNA synthesis in combination with other single or multiple kinase inhibitors, suggesting that MKs exert their effect upstream of ERK and P38 signaling (Figure 3A). Thus, our data suggests a negative regulatory role for $\mathrm{MKs}$ in mitogenic signaling through MEK/ERK. In good agreement with this data, $M K$-deficient cells (by MKi or shRNA-mediated knockdown $(s h M K))$ display sustained ERK1/2:T202/T204 phosphorylation (pERK; up to 90 to 120 minutes, compared to control cells) upon stimulation (Figure 3B, Additional file 3: Figure S3B,C). Conversely, $M K 3$ overexpression $(M K 3 O E)$ reduces both basal and induced $A T F 3$ transcription, and, in combination with $\mathrm{MEKi} / \mathrm{p} 38 \mathrm{i}$, further represses expression (Figure 3D). As predicted, $M K 3 O E$ delays ERK phosphorylation, consistent with an inhibitory action of MK3 on ERK activity and reduced target-gene induction (Figure 3B,D, Additional file 3: Figure S3B). MK2 was recently found to stabilize P38 in a kinase domainindependent manner, that is, physical association of MK2 to P38 controls P38 stability [33]. Analogous with 
this report, we detect a rise in P38 levels in $M K 3 O E$ cells versus reduced P38 levels in shMK cells; relevantly, P38 levels remain unaltered in $\mathrm{MKi}$ cells (Figure 3C, Additional file 3: Figure S3D). Contrary to pERK, P38: T180/T182 phosphorylation (pP38) is reduced in $M K 3 O E$ cells as well as in $s h M K$ and MKi cells. Also JNK:T183/T185 phosphorylation (pJNK) is reduced by shMK, whereas $M K 3 O E$ correlated with enhanced JNK levels (Additional file 3: Figure S3E,F). Although the full extent of factors and mechanisms controlling M/SAPK phosphorylation is not clear at this point, these findings are in keeping with multiple complex regulatory crossinteractions between MKs and M/SAPKs [3,34].

Consistent with our IF analyses (compare Figure 1C, Additional file 1: Figure S1B), H3S28 shows rapid and transitory phosphorylation kinetics in response to mitogens (Figure 3E). Relevantly, global H3S28ph is increased and sustained in MKi cells, whereas it is blunted in $M K 3 O E$ cells (Figure 3E) in line with altered PRC1 target gene expression under these respective conditions (compare Figure 3A,D). This data demonstrates that H3S28 phosphorylation kinetics respond to MK3 activity, and support a regulatory role for MK3 in epigenetic modulation of cell responses to environmental stimuli.

To gain further insight into the molecular mechanisms by which MK3 controls M/SAPK activity, we studied MEK, an ERK effector kinase. MEKpT292 and MEKpS298 were examined, as these two phosphoresidues are part of a mechanism that controls MEK activity [35]. Like pERK, MEKpT292 is also sustained in MK-deficient cells, suggesting that MK3 controls phosphatase activity directed toward upstream kinases (Figure 3F). Dual-specificity phosphatases (DUSPs) play important roles in feedback loops on phosphorylation cascades [36]. DUSP2 and DUSP5 induction meet the criteria of being dependent on mitogenic signaling and on $\mathrm{MK}$, as $M K 3 O E$ and MKi, enhance and decrease DUSP mRNA induction, respectively (Figure 3G). To validate the involvement of DUSPs in the negative regulatory network involving MK3, we used induction of EGR1 as a read-out for mitogen-induced ERK activity [37]. MKi cells display a stronger EGR1 induction (Additional file 4: Figure S4A), consistent with loss of negative regulation via ERK. To validate a role for phosphatase activity in regulation of the ERK/EGR1 response, cells were pretreated with orthovanadate, a generic DUSPs inhibitor (DUSPi). Enhanced EGR1 expression in the presence of DUSPi resembles that observed in MKi cells and supports a negative regulatory role for DUSPs in the MK3/ERK/EGR1 response (Additional file 4: Figure S4B); in line with reduced negative feedback in DUSPi cells, both pERK and pP38 are increased in response to mitogenic stimulation. Relevantly, also signaling-induced H3S28ph levels are enhanced significantly in the presence of DUSPi, in agreement with a functional role for DUSPs in epigenetic regulation (Additional file 4: Figure S4B). Relevantly, the reduced ERK phosphorylation by $M K 3 O E$ is partially reversed by DUSP inhibition, suggesting that DUSP activity acts as part of a relay system in the regulatory feedback of MK3 to MEK/ERK (Additional file 4: Figure S4C). Combined, the above findings support a negative regulatory role for MKs in MEK/ERK signaling, at least in part, via induction and/or activation of phosphatases.

To obtain independent proof for the functional relationship between MKs and M/SAPKs, we examined kinase interactions in Drosophila melanogaster. We first reproduced a signaling-induced interaction between $\mathrm{Ph}-\mathrm{p}$ (PHC1/2 ortholog) and $\mathrm{dMK} 2$ (the only $M K$ ortholog in D. $m e l$ ) in cultured insect cells (Additional file 5: Figure S5A). We next exploited Drosophila wing vein patterning to probe for M/SAPK-MK interaction in vivo. Wing vein formation in the fruit fly is dependent on MAPKs [38-40]. As expected, gain-of-function (GOF) lines for $d E R K /$ rolled (sd::Gal4 > UAS::rolled; D.mel ERK ortholog) show ectopic wing veins during wing imaginal disc development (Figure 4A,B). We here report that flies overexpressing $D$ p38b (sd::Gal4 > UAS::D-p38b; one of the D.mel P38 orthologs) also display enhanced ectopic vein formation (Figure 4A,B). Hence the ectopic vein phenotype can be used to gauge the effects of MK loss-of-function (LOF) on ERK/P38 pathway activity. To determine the effect of dMK2 on dERK and D-p38b, we crossed a transgenic RNAi-mediated $d M K 2$-knockdown line (v3171) to $d E R K$ and $D$-p38b-GOF lines (see: Methods section, Additional file 5: Figure S5B). $d M K 2-\mathrm{LOF}$ enhances the $d E R K-\mathrm{GOF}$ ectopic vein phenotype (Figure $4 \mathrm{~A}, \mathrm{~B}$ ). In contrast, $d M K 2$ LOF suppresses the ectopic vein phenotype induced by $D$ p38b-GOF (Figure 4A,B). Importantly, this data is fully congruent with our in vitro findings in mammalian cells and supports the existence of a complex genetic network between MAPKs, SAPKs and MKs. In conclusion, our in vivo experiments substantiate a negative regulatory role of $d M K 2$ on $d E R K$-signaling in wing vein development.

\section{Conclusions}

In summary, we here identify and carefully characterize a number of actors in PRC1-dependent gene regulation. Signaling through P38 has direct implications for local chromatin modulation (that is, H3S28 phosphorylation). We propose that ERK/PRC1/MK3 acts as a molecular dimmer switch that enables rapid and reversible transcriptional activation of ATF3. This mechanism defines negative feedback on Polycomb-mediated repression as an integral process in the regulation of appropriate cellular responses to environmental changes (Figure 5). Whereas part of the responses appears global, like H3S28 phosphorylation and CBX dissociation, the 


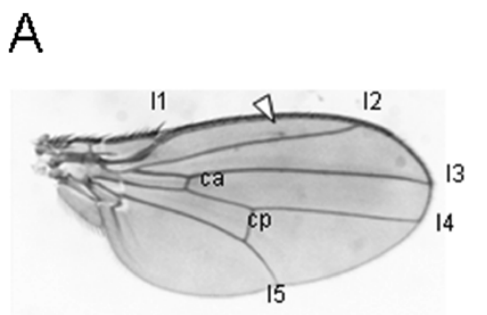

a) $s d:: G a i 4 / 4$

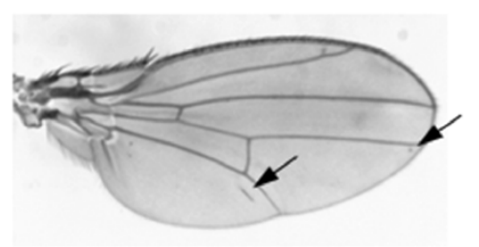

b) $s a:: G a 14>U A S:: 0-p 380$

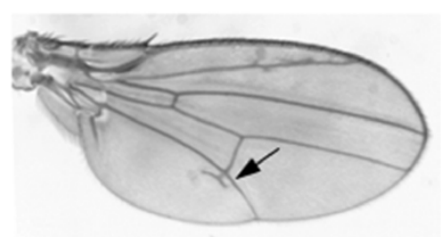

c) so::Gal4>UAS::rolled, $v 3171$
$\mathrm{B}$

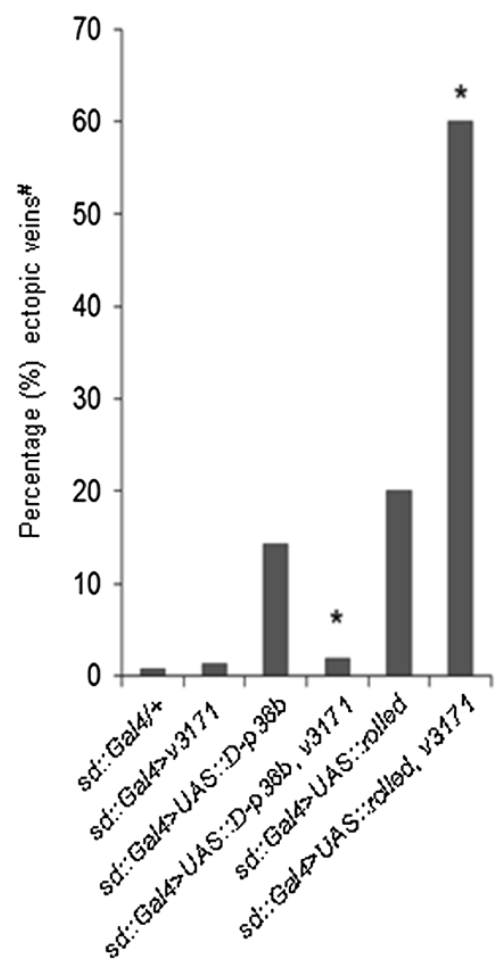

Figure 4 Negative feedback by $d M K 2$ on $d E R K /$ rolled in ectopic wing vein development. (A, B) Representative ectopic vein patterns (black arrows) in control (a) and transgenic lines $(\mathbf{b}, \mathbf{c})$; percentages of flies with ectopic wing veins in different genetic contexts (indicated below graph; B); \#: sd::Gal4 driver-induced ectopic veins nearby vein 2 (I2; white arrow head compare $\mathbf{A})$, were not scored; *: significantly different from corresponding genotype without dMK2-LOF (z-test; $P<0.001$ ).

presence of PRC1/MK3 likely contributes to chromatin targeting of pERK and provides specific local regulation. PRC-complex members are emerging as proteins harboring many different functions and binding partners [7]. We recently categorized \pm 120 known phosphorylation sites on a limited number of PRC proteins; many of these sites are predicted M/SAPK target sites and are likely to cooperate in gene regulation [41-44]. Although some phosphosites have been linked to PRC protein function [45-49], the biological relevance of the vast majority of these phosphorylation events is currently unknown. Our findings pave the way for detailed mutational analysis of the functional consequences of posttranslational modification of Polycomb proteins. The findings presented herein provide novel insight into differential regulation of PRC1 members in response to signaling and add to the growing recognition that PRC1-mediated repression is a highly dynamic process.

\section{Methods}

\section{Cell culture, viral infections}

Human U2-OS osteosarcoma cells and TIG3 primary human fibroblasts expressing the murine ecotropic receptor were kindly provided by Dr. D. Shvarts (Utrecht Medical Center, Utrecht, The Netherlands) and Dr. D. Peeper (Netherlands Cancer Institute (NKI), Amsterdam, The Netherlands), respectively. Expression vectors encoding the murine ecotropic receptor were a courtesy of Dr. R. Bernards (NKI, Amsterdam, The Netherlands). All human cell lines were cultured under standard conditions in DMEM containing 10\% fetal calf serum (FCS). Retroviral expression vectors were used to maximize percentages of expressing cells and to minimize integration effects. Production of infectious viral particles was carried out as described previously [50]. Briefly, ecotropic retroviral supernatants were produced by transfection of producer cells using calcium-phosphate co-precipitation. Forty to fortyeight hours post-transfection, the supernatants were harvested, filtered and stored at $-80^{\circ} \mathrm{C}$ until further use. Viral titers were sufficiently high to achieve near $100 \%$ infection. Cells were transduced with retrovirus in the presence of $4 \mu \mathrm{g} / \mathrm{ml}$ polybrene (Sigma-Aldrich, St. Louis, MO, USA) at around 25\% confluency for six to eight hours and then allowed to recover for forty-eight hours on fresh medium before selection pressure was applied. Transduced cells were grown for \pm 1 week on 1 to $4 \mu \mathrm{g} / \mathrm{ml}$ puromycin 


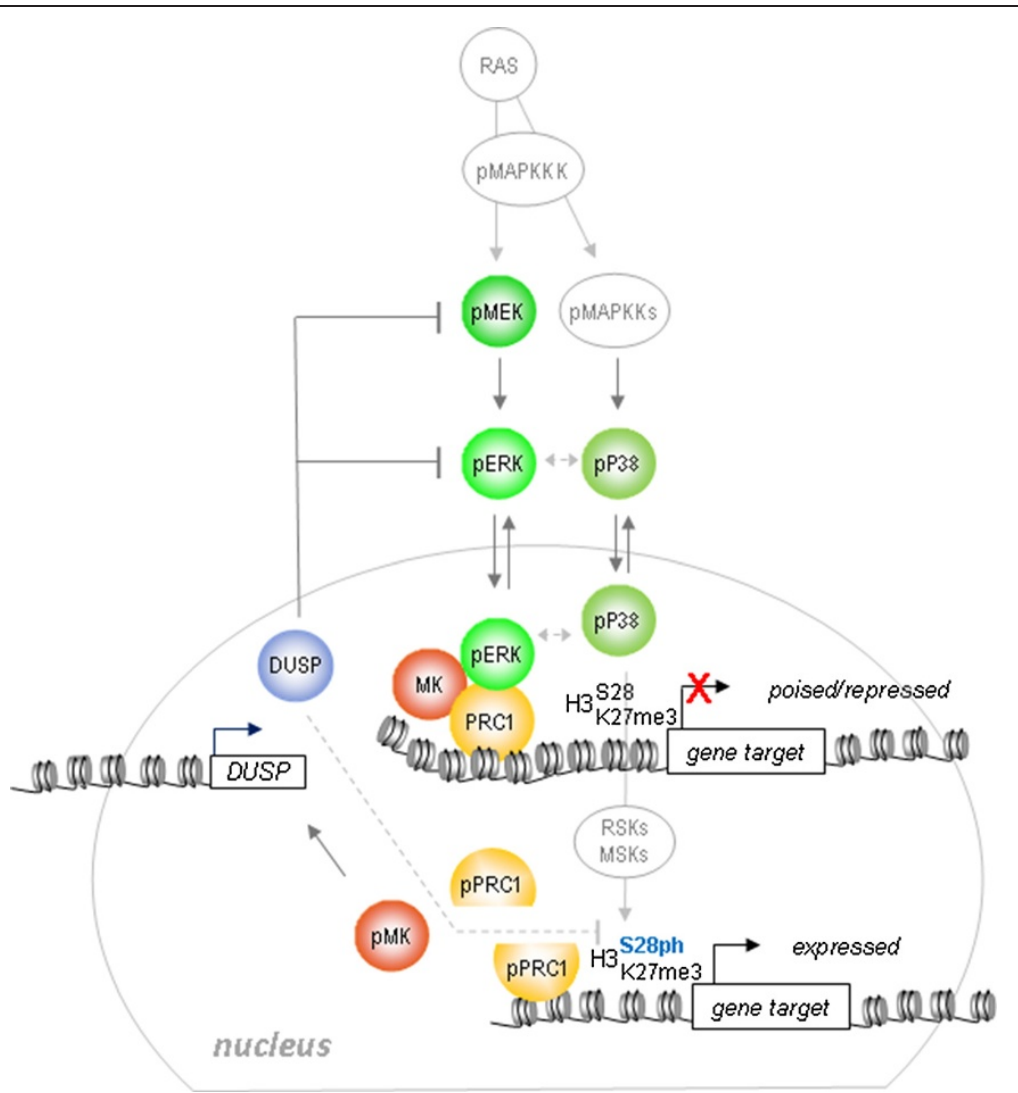

Figure 5 Model for MAPK/MK regulation of PRC1 target genes. The PRC1/MK/ERK module represents a molecular switch mechanism: fine-tuning of converging P38 and ERK signals at the chromatin level triggers a potential methylphosphoryl switching module and a signaling-dependent disruption of the PRC1/chromatin association that permits gene activation. Transient H3S28ph, but not removal of H3K27me3, accompanies gene expression. Concomitant MK activation initiates DUSP-dependent negative regulatory feedback on MEK/ERK (and possibly also on H3S28ph; dashed lines reflect potential functional relationships).

(Sigma) preceding experiments. Expression of all plasmid constructs was verified by immunoblotting.

Cells were serum-starved at $0.1 \%$ FCS for 48 hours. Mitogenic stimulation was achieved by supplementing 15\% FCS/100 ng/ml tetradecanoylphorbol acetate (TPA; Sigma) for 45 minutes or as indicated. Cells were pretreated with kinase inhibitors: 30 minutes $10 \mu \mathrm{M}$ MEK inhibitor (U0126; Promega, Madison, WI, USA), 30 minutes $10 \mu \mathrm{M}$ MK inhibitor (MK2a Inhibitor; Calbiochem/ Merck, Darmstadt, Germany), 30 minutes $20 \mu \mathrm{M}$ p38 inhibitor (SB202190; Calbiochem), 30 minutes $25 \mu \mathrm{M}$ JNK inhibitor (SP600125; Biomol, Plymouth Meeting, PA, USA), 30 minutes $85 \mu \mathrm{M}$ etoposide (ETP; Calbiochem). MK2a was confirmed to inhibit MK3 (data not shown). Cells were preincubated with sodium orthovanadate for 30 minutes prior to mitogenic stimulation at indicated concentration; control cells were incubated with solvent. Sodium selenite (Sigma) -treated cells (90 minutes $0.2 \mathrm{mM}$ ) were used as a positive control. Drosophila S2 cells were cultured at $25^{\circ} \mathrm{C}$ in Schneider medium with
$10 \%$ FCS. The day before transfection, $5.10^{6}$ cells were transferred in medium with $0.1 \%$ FCS. For transfection, $2 \mu \mathrm{g}$ of plasmid DNA were mixed with Effecten ${ }^{\mathrm{TM}}$ transfection reagent (Qiagen, Hilden, Germany) according to manufacturer's instructions (1/10 DNA-Effecten ${ }^{\mathrm{TM}}$ ratio). Forty-eight hours later, cells were either untreated, stimulated with $10 \% \mathrm{FCS} / 100 \mathrm{ng} / \mathrm{ml} \mathrm{TPA}$ or $0.5 \mathrm{mM}$ sodium meta-arsenite for two hours at $25^{\circ} \mathrm{C}$. For immunoprecipitation (IP) experiments, plasmids Act:: Myc-Ph and Act::EGFP-MAPKAP were co-transfected into S2 Drosophila cells grown in $0.1 \%$ FCS. IPs were performed as described (Mouchel-Vielh et al., 2011); IP antibodies are listed in Additional file 6: Table S1.

\section{Expression constructs}

Retroviral vectors (pBMN-LZRS.ires.GFP, pBMN-LZRS. ires.NEO) expressing murine BMI1-2Py or GST-MK3 have been described elsewhere [5,11]. Retroviral systems were used as published [51,52]. RNA-interfering MK3 
sequences were cloned into stable shRNA vectors [53]; targeting sequences: Additional file 7: Table S2.

The $d M K 2$ cDNA was amplified from clone SD05481 (Drosophila Genomics Resource Center; for oligonucleotides: see Additional file 7: Table S2). The resulting amplicon was introduced into pENTR/D-TOPO ${ }^{\text {TM }}$ (Invitrogen, Carlsbad, CA, USA), then transferred through LR-recombination into T. Murphy's vectors $p A W G$ (https://dgrc.cgb.indiana.edu/vectors). Similarly, a cDNA corresponding to the C-terminal part of Drosophila Polyhomeotic-proximal gene ( $P h$ or $P h-p)$ was amplified, introduced in pENTR/D-TOPO ${ }^{\mathrm{TM}}$, and subsequently transferred in $p A M W$ (for oligonucleotides: see Additional file 7: Table S2) [54]. Ph sequences in the Act::myc-Ph construct endoded the $346 \mathrm{C}$-terminal amino acids of the $\mathrm{Ph}$-proximal protein (GenPept qualifiers: NP_476871.2 GI:24639272) and included the SAM domain through which MK3 and PHC1/2 interact [5].

\section{Chromatin immunoprecipitation (ChIP) assays}

ChIPs on primary human fibroblasts were performed and analyzed essentially as described [12]. Cells were fixed for 10 minutes in 1\% formaldehyde/phosphate buffered saline (PBS) and stopped by 5 minutes incubation in glycine (final concentration: $0.125 \mathrm{M}$ ). Fixed cells were washed twice with PBS and harvested in SDS buffer $(50 \mathrm{mM}$ Tris at $\mathrm{pH} 8.1,100 \mathrm{mM} \mathrm{NaCl}, 0.5 \%$ SDS, and $5 \mathrm{mM}$ EDTA), supplemented with protease inhibitors (aprotinin, antipain and leupeptin all at $5 \mu \mathrm{g} / \mathrm{ml}$ and $1 \mathrm{mM}$ PMSF). Cells were pelleted by centrifugation, and suspended in IP buffer $(100 \mathrm{mM}$ Tris at $\mathrm{pH}$ 8.6, $100 \mathrm{mM} \mathrm{NaCl}, 0.3 \%$ SDS, $1.7 \%$ Triton X-100, and $5 \mathrm{mM}$ EDTA), containing protease inhibitors. Cells were disrupted by sonication, yielding genomic DNA fragments with a bulk size of 200 to $500 \mathrm{bp}$. For each IP, $1 \mathrm{ml}$ of lysate was precleared by adding $35 \mu \mathrm{l}$ of blocked protein A beads (Protein A-Sepharose/CL-4B (GE Healthcare, Piscataway, NJ, USA); $0.5 \mathrm{mg} / \mathrm{ml}$ fatty acid-free BSA (Sigma); and $0.2 \mathrm{mg} / \mathrm{ml}$ herring sperm DNA in TE buffer), followed by centrifugation. $10 \mu \mathrm{l}$ aliquots of precleared suspension were put aside as input DNA and kept at $4^{\circ} \mathrm{C}$. Samples were immunoprecipitated overnight at $4^{\circ} \mathrm{C}$. HA antiserum was used as negative control. Immune complexes were recovered by adding $40 \mu \mathrm{l}$ of blocked protein A or G beads (GE Healthcare) and incubated for 4 hours at $4^{\circ} \mathrm{C}$. Beads were washed three times in $1 \mathrm{ml}$ of mixed micelle buffer $(20 \mathrm{mM}$ Tris at $\mathrm{pH} 8.1$, $150 \mathrm{mM} \mathrm{NaCl}, 0.2 \%$ SDS, $1 \%$ Triton X-100, $5 \mathrm{mM}$ EDTA, and $5 \% \mathrm{w} / \mathrm{v}$ sucrose), twice in $1 \mathrm{ml}$ of buffer 500 (50 mM HEPES at $\mathrm{pH} 7.5,1 \%$ Triton X-100, $1 \mathrm{mM}$ EDTA, and $0.1 \% \mathrm{w} / \mathrm{v}$ sodium deoxycholate), twice in $1 \mathrm{ml}$ of $\mathrm{LiCl}$ detergent wash buffer $(10 \mathrm{mM}$ Tris at $\mathrm{pH}$ 8.0, $1 \mathrm{mM}$ EDTA, $0.5 \%$ sodium deoxycholate, $0.5 \%$ NP40 , and $250 \mathrm{mM} \mathrm{LiCl}$ ), and once in $1 \mathrm{ml} \mathrm{TE}$ buffer.
Immune complexes were eluted from beads in $250 \mu \mathrm{l}$ elution buffer (1\% SDS and 0.1 M NaHCO3) for 2 hours at $65^{\circ} \mathrm{C}$ (continuous shaking at $1000 \mathrm{rpm}$ ), and after centrifugation, supernatants were collected. $250 \mu \mathrm{l}$ elution buffer was added to input DNA samples and these were processed in parallel with eluted samples. Cross-links were reversed overnight at $65^{\circ} \mathrm{C}$, followed by 2 hours digestion with RNase $\mathrm{A}$ at $37^{\circ} \mathrm{C}$ and 2 hours proteinase $\mathrm{K}$ $(0.2 \mu \mathrm{g} / \mu \mathrm{l})$ at $55^{\circ} \mathrm{C}$. DNA fragments were recovered using QIAquick PCR purification columns, according to manufacturer's instructions (Qiagen, Hilden, Germany). Samples were eluted in $75 \mu \mathrm{l} \mathrm{EB}$ buffer and then diluted 1:5 in TE buffer. Immunoprecipitated DNA was quantified by real-time PCR (for ChIP antisera, primers: see Additional file 6: Tables S1, Additional file 7: Table S2). Each experiment was performed in triplicate. Results of one representative experiment are shown.

RNA isolation, CDNA synthesis, real-time (RT) PCR analysis For RT-PCR analysis, total RNA was isolated using Tri Reagent (Sigma) according to the manufacturer's protocol. Quantity and quality of the RNA were determined by $260 / 280 \mathrm{~nm}$ and $260 / 230 \mathrm{~nm}$ absorbance measurements, respectively, using the Nanodrop (Witec AG, Luzern, Switzerland). Total RNA (1 $\mu \mathrm{g})$ for each sample/ replicate was converted into first strand cDNA using the iScript $^{\mathrm{TM}}$ cDNA synthesis kit (Bio-Rad, Hercules, CA, USA) according to the manufacturer's instructions. Gene expression was determined by RT-PCR using the $\mathrm{MyiQ}^{\mathrm{TM}}$ thermal cycler (Bio-Rad) in combination with the IQ5 version 2.1 software (Bio-Rad). RT-PCR was performed on 25 ng of cDNA using the $\mathrm{qPCR}^{\mathrm{iQ}}{ }^{\mathrm{TM}}$ Custom SYBR ${ }^{\mathrm{TM}}$ Green Supermix with fluorescein (Bio-Rad) and 300nM primer in 96-well plates (Bio-Rad). For each primer pair a standard curve was generated with a serial dilution of a cDNA pool. RT-PCR data was analyzed according to the relative standard curve method. All values were normalized to either beta-Actin (Additional file 2: Figure S2) or cyclophillin A (Figures 1,3, Additional file 1: Figure S1, Additional file 3: Figure S3). The control condition is used as a reference. Primer sets for the selected genes were developed with Primer Express version 2.0 (Applied Biosystems, Foster City, CA, USA) using default settings (Additional file 7: Table S2).

\section{Immunofluorescence}

Cells were grown on 6- or 12-well culture plates (Greiner Bio-One, Alphen aan de Rijn, The Netherlands) to \pm 60 to $80 \%$ confluency, pretreated when applicable, washed twice with PBS, and either fixed for 15 minutes in $2 \%$ formaldehyde/PBS at room temperature (RT) followed by a 15 minutes incubation in chilled 100\% methanol $(\mathrm{MetOH})$ at $-20^{\circ} \mathrm{C}$, or directly fixed in $100 \%$ $\mathrm{MetOH}$ for 15 minutes at $-20^{\circ} \mathrm{C}$. Fixed plates were 
stored at $4^{\circ} \mathrm{C}$ in $70 \%$ ethanol (EtOH) or directly washed three times with PBS and used for immunocytochemistry (IC). For detection of PRC1 proteins and histone modifications, cells were first permeabilized for $10 \mathrm{~min}$ utes at $\mathrm{RT}$ in $0.2 \%$ Triton $\mathrm{X}-100(\mathrm{TrX})$ in PBS. After extensive washing in $\mathrm{PBS} / 0.02 \% \operatorname{TrX}$, cells were incubated with primary antibody (Additional file 6: Table S1) for 1.5 to 2.5 hours in a prewarmed humidified chamber at $37^{\circ} \mathrm{C}$, washed five times in $\mathrm{PBS} / 0.02 \% \operatorname{TrX}$ and incubated with fluorescently labeled secondary antibody for 60 minutes at $37^{\circ} \mathrm{C}$. 4'-6-diamidino-2-phenylindole (DAPI) was co-incubated with secondary conjugated antibodies to counterstain cell nuclei. Plates were washed in $\mathrm{PBS} / 0.02 \% \operatorname{TrX}$, rinsed in PBS and subsequently dehydrated: 1 minute in $70 \% \mathrm{EtOH}$, two times 1 minute in $100 \% \mathrm{EtOH}$ and air-dried. Cells were mounted in Vectashield (Vector Laboratories, Inc. Burlingame, CA, USA), analyzed using a Nikon TE200 Eclipse fluorescence microscope and photographed using a Nikon DXM1200 digital camera in combination with NIS-Elements 3.0 imaging software. All antibodies were diluted in blocking buffer (1\% BSA, 5\% FCS, 5\% normal goat serum (NGS), in PBS/0.02\% TrX). Secondary antisera used were goat-anti-mouse Texas $\operatorname{Red}^{\mathrm{TM}}$ (TXRD; 1:100; Southern Biotech, Birmingham, LA, USA) and goat anti-rabbit fluorescein isothiocyanate (FITC; 1:100; Southern Biotech), to detect monoclonal and polyclonal primary antibodies respectively.

\section{Protein isolation, differential extraction,} immunoprecipitation (IP), immunoblotting (IB)

Protein extraction and immunoblotting (IB) were performed and analyzed as described previously with minor adjustments [2,5]. For extraction, cells were washed twice with cold PBS and lysed in RIPA buffer $(50 \mathrm{mM}$ Tris at $\mathrm{pH}$ 8.0, $150 \mathrm{mM} \mathrm{NaCl}, 0.1 \%$ SDS, $5 \mathrm{mM}$ EDTA, $0.5 \% \mathrm{w} / \mathrm{v}$ sodium deoxycholate, and $1 \%$ NP-40) supplemented with protease and phosphatase inhibitors $(5 \mathrm{mM}$ benzamidine, $5 \mu \mathrm{g} / \mathrm{ml}$ antipain, $5 \mu \mathrm{g} / \mathrm{ml}$ leupeptin, $5 \mu \mathrm{g} / \mu \mathrm{L}$ aprotinin, $1 \mathrm{mM}$ sodium orthovanadate, $10 \mathrm{mM}$ sodium fluoride, $10 \mathrm{mM}$ pyrophosphate, $10 \mathrm{mM}$ ß-glycerophosphate, $0.5 \mathrm{mM}$ DTT, and $1 \mathrm{mM}$ PMSF). Lysates were subjected to two freeze-thaw cycles in liquid nitrogen, followed by sonication on ice with a probe sonicator (Soniprep 150; MSE, London, UK) for 12 cycli ( 1 sec ON, 1 sec OFF) with amplitude 5. After 10 minutes centrifugation at $13200 \mathrm{rpm}$ $\left(4^{\circ} \mathrm{C}\right.$; Eppendorf centrifuge), the supernatant was transferred to a fresh tube and protein concentration was determined using a BCA protein assay kit (Pierce/Thermo Fisher Scientific, Rockford, IL, USA) according to the manufacturer's protocols on a Benchmark 550 microplate reader (Bio-Rad).
For differential extraction, cells were washed two times with cold PBS and scraped in lysis buffer (Tris $\mathrm{HCl}$ at $\mathrm{pH} 7.5,150 \mathrm{mM} \mathrm{NaCl}, 0.5 \%$ Triton X-100, $1 \mathrm{mM}$ EDTA; supplemented with inhibitors). After 30 minutes incubation on ice, nuclei are collected in the pellet by centrifugation $\left(8000 \mathrm{rpm} ; 4^{\circ} \mathrm{C}\right)$ the supernatant is the cytoplasmic fraction. Nuclei are washed in lysis buffer and suspended in ELB buffer and incubated on ice for 10 minutes. Nuclear soluble (supernatant) and chromatin-bound fractions (pellet) are separated by centrifugation $\left(13200 \mathrm{rpm} ; 4^{\circ} \mathrm{C}\right)$. After an additional wash in ELB buffer, the pellets were suspended in ELB buffer and sonicated.

For IP, cells were either cross-linked followed by cell lysis, or cells were lysed directly in ELB buffer $(50 \mathrm{mM}$ HEPES at pH 7.0, $250 \mathrm{mM} \mathrm{NaCl}, 5 \mathrm{mM}$ EDTA, and $0.1 \%$ NP-40) supplemented with $5 \mathrm{mM}$ benzamidine, $5 \mu \mathrm{g} / \mathrm{ml}$ antipain, $5 \mu \mathrm{g} / \mathrm{ml}$ leupeptin, $5 \mu \mathrm{g} / \mathrm{ml}$ aprotinin, $1 \mathrm{mM}$ sodium vanadate, $10 \mathrm{mM}$ sodium fluoride, $10 \mathrm{mM}$ pyrophosphate, $10 \mathrm{mM}$ ß-glycerophosphate, $0.5 \mathrm{mM}$ DTT, and $1 \mathrm{mM}$ PMSF. For cross-linking, cells were incubated in $1 \%$ formaldehyde (in PBS) for $10 \mathrm{~min}$ utes at RT, fixation was stopped by addition of $2 \mathrm{M}$ glycin to a final concentration of $0.125 \mathrm{M}$. After 5 minutes incubation, cells were washed twice in cold PBS and lysed in ELB buffer. IP was carried out as described $[11,15]$. Briefly, extracts were sonicated on ice, centrifuged for 10 minutes at $4{ }^{\circ} \mathrm{C}$ at $13200 \mathrm{rpm}$ and supernatants were transferred to a precooled tube; $10 \%$ of the supernatant was taken as input and stored at $-80^{\circ} \mathrm{C}$. Appropriate amount of antiserum (Additional file 6: Table S1) was added and tubes were rotated for 1 hour at $4^{\circ} \mathrm{C}$ on a spinning wheel. To precipitate immune complexes, washed protein G beads (Protein G Sepharose/4 Fast Flow; GE Healthcare) were added to the extracts and rotated for 3 to 4 hours at $4^{\circ} \mathrm{C}$, followed by 3 minutes centrifugation at $3000 \mathrm{rpm}$ at $4^{\circ} \mathrm{C}$. Supernatant was collected as depleted fraction and stored at $-80^{\circ} \mathrm{C}$. Beads were washed four times in ELB buffer (with supplements) and stored dry at $-80^{\circ} \mathrm{C}$ until IB analysis.

For IB, equal protein amounts were boiled in sample buffer for 5 minutes and loaded on 9 to 15\% polyacrylamide gels. Following separation by SDSPAGE, proteins were transferred onto polyvinylidene fluoride (PVDF) membranes (GE Healthcare). Ponceau S (Sigma) staining was used to check protein transfer. PVDF membranes were blocked with 3.4\% non-fat dry milk (Protifar; Nutricia, Zoetermeer, the Netherlands) in PBS containing 0.1\% Tween $20(\mathrm{pH}$ 7.5) for 1 hour at RT, followed by an overnight incubation at $4^{\circ} \mathrm{C}$ with the primary antibody (Additional file 6: Table S1; anti-CBX4 [55]). After extensive washing with $\mathrm{PBS} / 0.2 \%$ Tween 20 , membranes were probed with corresponding horseradish peroxidase- 
conjugated secondary antibodies for 1 hour at RT: goat anti-rat (7077; 1:2,000; Cell Signaling, Danvers, MA, USA), rat anti-mouse (P0260; 1:5,000; DAKO, Glostrup, Denmark) and donkey anti-rabbit (711035152; 1:15,000; Jackson Lab, Bar Harbor, ME, USA), to detect monoclonal rat, monoclonal mouse and rabbit polyclonal primary antibodies respectively. Signals were detected on autoradiograms using enhanced chemoluminescence (ECL; Pierce). Intensity of the bands was quantified with Quantity One software (Bio-Rad).

\section{Drosophila lines}

Drosophila melanogaster stocks and crosses were kept on standard media at $25^{\circ} \mathrm{C}$. For crosses, five females were mated with five males; they were transferred each 48 hours in new tubes. The $w^{1118}$ line was used as control line. The UAS::rolled line was a gift from Dr. K. Moses (University of Cambridge, Cambridge, UK); the $U A S:: D-p 38 b$ was a gift from Dr. JM Gibert (University of Geneva, Geneva, Switzerland); UAS::rolled and UAS:: $D-p 38 b$ allow $d E R K$ and $D-p 38 b$ overexpression, respectively $[38,56]$. The $v 3171$ line ( $w^{1118}$; MAPk-Ak2 ${ }^{\text {GD1597})}$ that downregulates $d M K 2$ by RNA interference, was purchased from the Vienna Drosophila RNAi Center (VDRC) [57]; it does not present any known off-target effects. Downregulation of $d M K 2$ in third instar larvae was verified by real-time (RT) PCR using primers located outside the $v 3171$ repeats (Additional file 5: Figure S5B) as described [41]. Results were normalized against rp49 or Spt6 (Additional file 7: Table S2). Transgene overexpression was achieved using the wingspecific Gal4 transgenic driver scalloped $s d^{29.1}$ (called sd::Gal4; BL-8609 line; Bloomington Drosophila Stock Center (BDSC), Bloomington, IN, USA)). All the transgenic lines display Gal4-independent mini-white expression that allows tracing of transgene transmission. $d M K 2$-LOF and $h M K 3-$ GOF transgenic flies were also crossed to mutant Polycomb lines to study a potential interaction of MK and PcG in vivo. Neither $h M K 3-G O F$ nor $d M K 2$-LOF induce a discernable sexcomb-phenotype by themselves or in combination with established $P c^{1}$ and $\mathrm{Scm}^{D 1}$ alleles in heterozygote crosses (data not shown). The most likely explanation for this lack of phenotype is that $d M K 2$ may not play a role in anteroposterior (AP) patterning. In support of the latter, $\mathrm{AP}$-axis abnormalities have not been reported in single or double MK2/3 knockout mice [34].

\section{Additional files}

Additional file 1: Figure S1. PRC1 target gene expression is controlled by ERK and P38. (A). MAPK and SAPK phosphorylation in response to mitogenic stimulation (stim) in U2-OS cells; specificity of response was supported by distinctive phosphorylation profiles induced by two different stressors (ETP: etoposide, Se: selenite). (B) H3S28ph and PRC1 protein (BMI1) staining in G1-arrested (starved) or mitogen-stimulated U2OS cells. (C) Quantification of chromatin-bound BMI1 levels (compare Figure 1D) in mitogen-stimulated cells pretreated with kinase inhibitors (indicated); BMI1 levels were normalized versus histone H3. (D) Interaction of pERK and BMI1; U2-OS/BMI2Py cells were stimulated with mitogen (stim) prior to IP; $\mathrm{t}+$ : longer exposure (IB: immunoblot; IP: immunoprecipitation). Parallel experiments with pP38 were inconclusive due to IB detection issues with applied antisera.

Additional file 2: Figure S2. PRC1/chromatin dissociation, not loss of H3K27me3, correlates with transcription. (A) mRNA expression of PRC1 target and non-target genes in TIG3 cells upon 0,45 and 90 min of mitogen-stimulation. (B) Mitogenic stimulation induces BMI phosphorylation (upper panel; pBMI1) in TIG3 cells; cellular BMI1 and CBX8 protein (lower panel) levels remain unchanged under these conditions in support of changed PRC1/chromatin association rather than loss of protein (for example, degradation).

Additional file 3: Figure S3. MK3 is a negative regulator of ERK. (A) mRNA expression of PRC1 target gene ATF3 as a function of kinase inhibition in TIG3 cells (data as in Figure 3A) and U2-OS cells. (B) Quantification of pERK profiles (compare Figure $3 \mathrm{~B}$ ) in control versus MK3OE cells (left panel) and in control versus MKi cells (right panel); pERK levels were normalized to beta Actin (b-Actin). (C-F) IB-analysis of (p)ERK (C), (p)P38 (D), (p)JNK (E) in resting or mitogen-stimulated (stim) control and MK-knockdown (shMK) cells and (F) in the context of MK3OE; $\mathrm{t}(\mathrm{min})$ : time post-stimulation in minutes. Samples corresponding to control (con) and experiment (MK3OE or shMK) were always loaded on the same gel to enable direct quantitative comparison; *: loading controls for all corresponding panels; $\mathrm{t}+$ : longer exposure.

Additional file 4: Figure S4. DUSP involvement in regulation of MK3/ ERK. (A) IB analysis of ERG1 in resting or mitogen-stimulated (stim) control (con) and MK-inhibited (MKi) cells; t (min): time post-stimulation in minutes. Samples corresponding to control and experiment (shMK) were always loaded on the same gel to enable direct quantitative comparison. (B) Cells were pretreated with DUSP inhibitor (DUSPi; concentration indicated) prior to mitogenic stimulation. IB detection of proteins as indicated. (C) Cells were pretreated with $50 \mu \mathrm{M}$ DUSPi prior to mitogen stimulation. Samples corresponding to control and experiment (MK3OE) were always loaded on the same gel (bottom panel) to enable direct quantitative comparison. Quantitative analysis of effects of DUSPi in control cells (con; left panel) and MK3OE cells (right panel); normalization pERK levels was done versus beta Actin (b-Actin).

Additional file 5: Figure S5. PRC1/MK/ERK module represents a molecular switch mechanism. (A) Functional interaction between dMK2 and Polyhomeotic in vitro: stress signaling-induced interaction of EGFPtagged dMK2 (Drosophila ortholog of MK2/3) and Myc-tagged Ph (Drosophila ortholog of PHC1/2) in S2 cells. The Myc-Ph sequences comprised the C-terminal SAM domain [54]. Conditions tested: starved, mitogen-stimulated (FCS/TPA) and stressed (arsenite). IgG represents IgGheavy and -light chains. (B) Reduced dMK2 expression in third instar v3171 larvae; normalization indicated.

Additional file 6: Table S1. Antibodies used for ChIP, ICC, IB and IP. Additional file 7: Table S2. Primer sequences and targeting sequences.

\section{Competing interests}

The authors declare that they have no competing interests.

\section{Authors' contributions}

$P P, E M-V, Y T, U R R, F P, J W V$ conceived of the study design; PP, HN, EM-V, GVdA, FS, VD, CG, MA, FP, JWV performed the experiments and analysis; PP, FP, and JWV drafted the manuscript. All authors read and approved the final manuscript.

\section{Acknowledgements}

We thank S. Bloyer, A. Catling, J. Geraedts, K. Hansen, M. Inagaki, M. van Lohuizen, S. Ludwig, M. Mooij, A. Otten, M. Schepens, R. Sverdlov, T. van de Weijer, B. Wouters, the MAASTRO and MolGen departments for research 
materials, technical support and scientific discussions. Financial support: Dutch Science Organization (ZonMW-NWO): Research Support grant 908-02040 (JWV); VIDI grant 016.046.362 (JWV), joint van Gogh grant (JWW, FP); tUL Grant (JWV); VSB Fonds scholarship (PP); Netherlands Genome Initiative (NGI) fellowship 050-72-422 (HN); UPMC and CNRS (FP).

\section{Author details}

'Department of Molecular Genetics, GROW School for Oncology and Developmental Biology, Maastricht University, Universiteitssingel 50, 6229ER Maastricht, The Netherlands. ${ }^{2}$ BiGCaT Bioinformatics, Maastricht University, Universiteitssingel 50, 6229ER, Maastricht, The Netherlands. ${ }^{3}$ Laboratoire de Biologie du Développement UMR 7622, Centre National de la Recherche Scientifique, Université Pierre et Marie Curie-Paris 6, 9 Quai Saint-Bernard, 75005, Paris, France. ${ }^{4}$ Department of Stem Cell Biology, Research Institute for Radiation Biology and Medicine, Hiroshima University, 1-2-3, Kasumi, Minami-ku, Hiroshima, Japan. ${ }^{5}$ Department of Molecular Biology, Max Planck Institute of Biochemistry, Am Klopferspitz 18, D-82152, Martinsried, Germany.

\section{Received: 4 April 2012 Accepted: 11 July 2012}

Published: 7 August 2012

\section{References}

1. Keshet $Y$, Seger $R$ : The MAP kinase signaling cascades: a system of hundreds of components regulates a diverse array of physiological functions. Methods Mol Biol 2010, 661:3-38.

2. Ludwig S, Engel K, Hoffmeyer A, Sithanandam G, Neufeld B, Palm D, Gaestel M, Rapp UR: 3pK, a novel mitogen-activated protein (MAP) kinaseactivated protein kinase, is targeted by three MAP kinase pathways. Mol Cell Biol 1996, 16:6687-6697.

3. Gaestel M: Specificity of signaling from MAPKs to MAPKAPKs: kinases' tango nuevo. Front Biosci 2008, 13:6050-6059.

4. Shiryaev A, Moens U: Mitogen-activated protein kinase p38 and MK2, MK3 and MK5: menage a trois or menage a quatre? Cell Signal 2010, 22:1185-1192

5. Voncken JW, Niessen $H$, Neufeld B, Rennefahrt U, Dahlmans V, Kubben N Holzer B, Ludwig S, Rapp UR: MAPKAP kinase 3pK phosphorylates and regulates chromatin-association of the Polycomb-group protein Bmi1. J Biol Chem 2005, 280:5178-5187.

6. Prezioso C, Orlando V: Polycomb proteins in mammalian cell differentiation and plasticity. FEBS Lett 2011, 585:2067-2077.

7. Simon JA, Kingston RE: Mechanisms of Polycomb gene silencing: knowns and unknowns. Nat Rev Mol Cell Biol 2009, 10:697-708.

8. Azuara V, Perry P, Sauer S, Spivakov M, Jorgensen HF, John RM, Gouti M, Casanova M, Warnes G, Merkenschlager M, Fisher AG: Chromatin signatures of pluripotent cell lines. Nat Cell Biol 2006, 8:532-538.

9. Bernstein BE, Mikkelsen TS, Xie X, Kamal M, Huebert DJ, Cuff J, Fry B, Meissner A, Wernig M, Plath K, Jaenisch R, Wagschal A, Feil R, Schreiber SL, Lander ES: A bivalent chromatin structure marks key developmental genes in embryonic stem cells. Cell 2006, 125:315-326.

10. Mikkelsen TS, Ku M, Jaffe DB, Issac B, Lieberman E, Giannoukos G, Alvarez P, Brockman W, Kim TK, Koche RP, Lee W, Mendenhall E, O'Donovan A, Presser A, Russ C, Xie X, Meissner A, Wernig M, Jaenisch R, Nusbaum C, Lander ES, Bernstein BE: Genome-wide maps of chromatin state in pluripotent and lineage-committed cells. Nature 2007, 448:553-560.

11. Voncken JW, Schweizer D, Aagaard L, Sattler L, Jantsch MF, van Lohuizen M: Chromatin-association of the Polycomb group protein BMI1 is cell cycle-regulated and correlates with its phosphorylation status. I Cell Sci 1999, 112:4627-4639.

12. Bracken AP, Dietrich N, Pasini D, Hansen KH, Helin K: Genome-wide mapping of Polycomb target genes unravels their roles in cell fate transitions. Genes Dev 2006, 20:1123-1136.

13. Tarn C, Bilodeau ML, Hullinger RL, Andrisani OM: Differential immediate early gene expression in conditional hepatitis $B$ virus $\mathrm{pX}$-transforming versus nontransforming hepatocyte cell lines. J Biol Chem 1999, 274:2327-2336.

14. Ronkina N, Menon MB, Schwermann J, Arthur JS, Legault H, Telliez JB, Kayyali US, Nebreda AR, Kotlyarov A, Gaestel M: Stress induced gene expression: a direct role for MAPKAP kinases in transcriptional activation of immediate early genes. Nucleic Acids Res 2010, 39:2503-2518.

15. Alkema MJ, Bronk M, Verhoeven E, Otte A, van't Veer $\sqcup$, Berns $A$, van Lohuizen M: Identification of Bmi1-interacting proteins as constituents of a multimeric mammalian polycomb complex. Genes Dev 1997, 11:226240.

16. Saurin AJ, Shiels C, Williamson J, Satijn DP, Otte AP, Sheer D, Freemont PS: The human polycomb group complex associates with pericentromeric heterochromatin to form a novel nuclear domain. J Cell Biol 1998, 142:887-898.

17. Perez-Cadahia B, Drobic B, Davie JR: H3 phosphorylation: dual role in mitosis and interphase. Biochem Cell Biol 2009, 87:695-709.

18. Sassone-Corsi P, Mizzen CA, Cheung P, Crosio C, Monaco L, Jacquot S, Hanauer $\mathrm{A}$, Allis CD: Requirement of Rsk-2 for epidermal growth factor-activated phosphorylation of histone H3. Science 1999, 285:886-891.

19. Drobic B, Perez-Cadahia B, Yu J, Kung SK, Davie JR: Promoter chromatin remodeling of immediate-early genes is mediated through $\mathrm{H} 3$ phosphorylation at either serine 28 or 10 by the MSK1 multi-protein complex. Nucleic Acids Res 2010, 38:3196-3208.

20. Cao R, Tsukada YI, Zhang Y: Role of Bmi-1 and Ring1A in H2A ubiquitylation and Hox gene silencing. Mol Cell 2005, 20:845-854

21. Hodgson JW, Argiropoulos B, Brock HW: Site-specific recognition of a 70-base-pair element containing $d(G A)(n)$ repeats mediates bithoraxoid polycomb group response element-dependent silencing. Mol Cell Biol 2001, 21:4528-4543.

22. Boyer LA, Plath K, Zeitlinger J, Brambrink T, Medeiros LA, Lee TI, Levine SS, Wernig M, Tajonar A, Ray MK, Bell GW, Otte AP, Vidal M, Gifford DK, Young $R A$, Jaenisch R: Polycomb complexes repress developmental regulators in murine embryonic stem cells. Nature 2006, 441:349-353.

23. Lee TI, Jenner RG, Boyer LA, Guenther MG, Levine SS, Kumar RM, Chevalier B, Johnstone SE, Cole MF, Isono K, Koseki H, Fuchikami T, Abe K, Murray HL, Zucker JP, Yuan B, Bell GW, Herbolsheimer E, Hannett NM, Sun K, Odom DT, Otte AP, Volkert TL, Bartel DP, Melton DA, Gifford DK, Jaenisch R, Young RA: Control of developmental regulators by polycomb in human embryonic stem cells. Cell 2006, 125:301-313.

24. Lau PN, Cheung P: Histone code pathway involving H3 S28 phosphorylation and $\mathrm{K} 27$ acetylation activates transcription and antagonizes polycomb silencing. Proc Natl Acad Sci USA 2011, 108:2801-2806.

25. Gehani SS, Agrawal-Singh S, Dietrich N, Christophersen NS, Helin K, Hansen $\mathrm{K}$ : Polycomb group protein displacement and gene activation through MSK-dependent H3K27me3S28 phosphorylation. Mol Cell 2010, 39:886900 .

26. Young MD, Willson TA, Wakefield MJ, Trounson E, Hilton DJ, Blewitt ME, Oshlack A, Majewski IJ: ChIP-seq analysis reveals distinct H3K27me3 profiles that correlate with transcriptional activity. Nucleic Acids Res 2011, 39:7415-7427.

27. Hirota T, Lipp JJ, Toh BH, Peters JM: Histone H3 serine 10 phosphorylation by Aurora B causes HP1 dissociation from heterochromatin. Nature 2005, 438:1176-1180.

28. Fischle W, Tseng BS, Dormann HL, Ueberheide BM, Garcia BA, Shabanowitz J, Shabanowitz J, Hunt DF, Funabiki H, Allis CD: Regulation of HP1-chromatin binding by histone $\mathrm{H} 3$ methylation and phosphorylation. Nature 2005, 438:1116-1122.

29. Dormann $H L$, Tseng BS, Allis CD, Funabiki $H$, Fischle W: Dynamic regulation of effector protein binding to histone modifications: the biology of HP1 switching. Cell Cycle 2006, 5:2842-2851.

30. Hansen KH, Bracken AP, Pasini D, Dietrich N, Gehani SS, Monrad A, Rappsilber J, Lerdrup M, Helin K: A model for transmission of the H3K27me3 epigenetic mark. Nat Cell Biol 2008, 10:1291-1300. Epub ahead of print

31. Stojic L, Jasencakova Z, Prezioso C, Stutzer A, Bodega B, Pasini D, Klingberg R, Mozzetta C, Margueron R, Puri PL, Schwarzer D, Helin K, Fischle W, Orlando V: Chromatin regulated interchange between polycomb repressive complex 2 (PRC2)-Ezh2 and PRC2-Ezh1 complexes controls myogenin activation in skeletal muscle cells. Epigenetics Chromatin 2011, 4:16.

32. Vermeulen M, Eberl HC, Matarese F, Marks H, Denissov S, Butter F, Lee KK, Olsen JV, Hyman AA, Stunnenberg HG, Mann M: Quantitative interaction proteomics and genome-wide profiling of epigenetic histone marks and their readers. Cell 2010, 142:967-980.

33. Ronkina N, Kotlyarov A, Dittrich-Breiholz O, Kracht M, Hitti E, Milarski K, Askew R, Marusic S, Lin L-L, Gaestel M, Telliez J-B: The mitogen-activated protein kinase (MAPK)-activated protein kinases MK2 and MK3 cooperate in stimulation of tumor necrosis factor biosynthesis and stabilization of p38 MAPK. Mol Cell Biol 2007, 27:170-181. 
34. Ronkina N, Kotlyarov A, Gaestel M: MK2 and MK3 - a pair of isoenzymes? Front Biosci 2008, 13:5511-5521.

35. Eblen ST, Slack-Davis JK, Tarcsafalvi A, Parsons JT, Weber MJ, Catling AD: Mitogen-activated protein kinase feedback phosphorylation regulates MEK1 complex formation and activation during cellular adhesion. $\mathrm{Mol}$ Cell Biol 2004, 24:2308-2317.

36. Patterson Kl, Brummer T, O'Brien PM, Daly RJ: Dual-specificity phosphatases: critical regulators with diverse cellular targets. Biochem $J$ 2009, 418:475-489.

37. Wenzel K, Daskalow K, Herse F, Seitz S, Zacharias U, Schenk JA, Schulz H, Hubner N, Micheel B, Schlag PM, Osterziel KJ, Ozcelik C, Scherneck S, Jandrig B: Expression of the protein phosphatase 1 inhibitor KEPI is downregulated in breast cancer cell lines and tissues and involved in the regulation of the tumor suppressor EGR1 via the MEK-ERK pathway. Biol Chem 2007, 388:489-495.

38. Adachi-Yamada T, Nakamura M, Irie K, Tomoyasu Y, Sano Y, Mori E, Goto S, Ueno N, Nishida Y, Matsumoto K: p38 mitogen-activated protein kinase can be involved in transforming growth factor beta superfamily signal transduction in Drosophila wing morphogenesis. Mol Cell Biol 1999, 19:2322-2329.

39. De Celis JF: Pattern formation in the Drosophila wing: the development of the veins. BioEssays 2003, 25:443-451.

40. Martin-Blanco E: p38 MAPK signalling cascades: ancient roles and new functions. BioEssays 2000, 22:637-645.

41. Mouchel-Vielh E, Rougeot J, Decoville M, Peronnet F: The MAP kinase ERK and its scaffold protein MP1 interact with the chromatin regulator Corto during Drosophila wing tissue development. BMC Dev Biol 2011, 11:17.

42. Niessen HE, Demmers JA, Voncken JW: Talking to chromatin: posttranslational modulation of polycomb group function. Epigenetics Chromatin 2009, 2:10.

43. Rao PS, Satelli A, Zhang S, Srivastava SK, Srivenugopal KS, Rao US: RNF2 is the target for phosphorylation by the p38 MAPK and ERK signaling pathways. Proteomics 2009, 9:2776-2787.

44. Srivastav RK, Schwede S, Klaus M, Schwermann J, Gaestel M, Niedenthal R: Monitoring protein-protein interactions in mammalian cells by transSUMOylation. Biochem J 2011, 438:495-503.

45. Chen S, Bohrer LR, Rai AN, Pan Y, Gan L, Zhou X, Bagchi A, Simon JA, Huang $\mathrm{H}$ : Cyclin-dependent kinases regulate epigenetic gene silencing through phosphorylation of EZH2. Nat Cell Biol 2010, 12:1108-1114.

46. Fujisaki S, Ninomiya $Y$, Ishihara H, Miyazaki M, Kanno R, Asahara T, Kanno M: Dimerization of the Polycomb-group protein Mel-18 is regulated by PKC phosphorylation. Biochem Biophys Res Commun 2003, 300:135-140.

47. Kaneko S, Li G, Son J, Xu CF, Margueron R, Neubert TA, Reinberg D: Phosphorylation of the PRC2 component Ezh2 is cell cycle-regulated and up-regulates its binding to ncRNA. Genes Dev 2010, 23:2615-2620.

48. Roscic A, Moller A, Calzado MA, Renner F, Wimmer VC, Gresko E, Ludi KS, Schmitz ML: Phosphorylation-dependent control of PC2 SUMO E3 ligase activity by its substrate protein HIPK2. Mol Cell 2006, 24:77-89.

49. Wei $Y$, Chen Y-H, Li L-Y, Lang J, Yeh S-P, Shi B, Yang CC, Yang JY, Lin CY, Lai CC, Hung MC: CDK1-dependent phosphorylation of EZH2 suppresses methylation of $\mathrm{H} 3 \mathrm{~K} 27$ and promotes osteogenic differentiation of human mesenchymal stem cells. Nat Cell Biol 2011, 13:87-94.

50. Serrano M, Lin AW, McCurrach ME, Beach D, Lowe SW: Oncogenic ras provokes premature cell senescence associated with accumulation of p53 and p16INK4a. Cell 1997, 88:593-602.

51. Kinsella TM, Nolan GP: Episomal vectors rapidly and stably produce hightiter recombinant retrovirus. HumGene Ther 1996, 7:1405-1413.

52. Morgenstern JP, Land H: Advanced mammalian gene transfer: high titre retroviral vectors with multiple drug selection markers and a complementary helper-free packaging cell line. Nucleic Acids Res 1990, 18:3587-3596

53. Brummelkamp TR, Bernards R, Agami R: A system for stable expression of short interfering RNAs in mammalian cells. Science 2002, 296:550-553.

54. Peterson AJ, Kyba M, Bornemann D, Morgan K, Brock HW, Simon J: A domain shared by the Polycomb group proteins $\mathrm{Scm}$ and ph mediates heterotypic and homotypic interactions. Mol Cell Biol 1997, 17:6683-6692.

55. Hamer KM, Sewalt RG, den Blaauwen JL, Hendrix T, Satijn DP, Otte AP: A panel of monoclonal antibodies against human polycomb group proteins. Hybrid Hybridomics 2002, 21:245-252.

56. Kumar JP, Moses K: EGF receptor and Notch signaling act upstream of Eyeless/Pax6 to control eye specification. Cell 2001, 104:687-697.
57. Dietzl G, Chen D, Schnorrer F, Su KC, Barinova Y, Fellner M, Gasser B, Kinsey K, Oppel S, Scheiblauer S, Couto A, Marra V, Keleman K, Dickson BJ: A genome-wide transgenic RNAi library for conditional gene inactivation in Drosophila. Nature 2007, 448:151-156.

doi:10.1186/1756-8935-5-12

Cite this article as: Prickaerts et al:: MK3 controls Polycomb target gene expression via negative feedback on ERK. Epigenetics \& Chromatin 2012 $5: 12$.

\section{Submit your next manuscript to BioMed Central and take full advantage of:}

- Convenient online submission

- Thorough peer review

- No space constraints or color figure charges

- Immediate publication on acceptance

- Inclusion in PubMed, CAS, Scopus and Google Scholar

- Research which is freely available for redistribution 